\title{
Herbage production of Mediterranean grassland under sea- sonal and yearlong grazing systems
}

\author{
MARIO GUTMAN, NOAM G. SELIGMAN, AND IMANUEL NOY-MEIR
}

\section{Abstract}

Data from 2 consecutive grazing experiments conducted over 7 years on a Mediterranean type grassland were used to calculate forage consumption by herds of beef cattle maintained at different stocking rates and in different grazing systems. In the first experiment the animals were on the experimental range for 8 months of the year; in the second, grazing was yearlong. Total production of herbage mass was estimated from these data and from the residual litter in the paddocks at the end of the dry season. Production of dry herbage mass varied between 2,600 and $3,800 \mathrm{~kg} / \mathrm{ha}$, with a mean and SD of $3,060 \pm 300 \mathrm{~kg} / \mathrm{ha}$. While variation between years was relatively small but significant $(P<.01)$, the effect of stocking rate or grazing system (seasonal, yearlong) was smaller and not significant. It is concluded that the attained level of herbage production of Mediterranean grassland on relatively shallow basaltic protogrumosols is not senoitive to total precipitation over a very wide range or to grazing system. It may be dependent on the availablity of nutrients, especially nitrogen, and the seasonal distribution pattern of available soll molature in a restricted rooting zone.

Key Words: continuous grazing, rotational grazing, forage consumption, supplemental feeding

In order to determine herbage production of rangeland under grazing, it is necessary to solve methodological and logistic problems encountered in estimating long-term intake of forage by the herd and in sampling herbage on large, heterogeneous range units. It is therefore not easy to determine quantitatively the degree to which environmental and management factors limit rangeland productivity in different situations. Annual herbage production has been shown to depend on various environmental factors, in particular precipitation and soil moisture (Le Houerou and Hoste 1977, Murphy 1970), radiation and temperature (Wallach and Gutman 1976), temperature indices like accumulated degree days (George et al. 1988), soil nitrogen, and phosphorus (van Keulen 1975, Penning de Vries and Djiteye 1982, Benjamin et al. 1982). Effects of stocking rate or grazing system on annual herbage production are superimposed on the environmental effects and may interact with them. The effect of defoliation by grazing is dependent not only on the severity of the grazing, but also on the ecology of the habitat (Noy-Meir and Walker 1986). In seasonal ranges, the end of the season can be abrupt when it is caused by photoperiodically induced maturity or by drastic weather change, like the hot, searing winds in the Mediterranean region; or it can depend on the availability and rate of depletion of a resource like water or nutrients. In the first case, increasing grazing pressure should, in theory, reduce primary production; in the second case, not necessarily so (Noy-Meir 1978).

Data obtained over 7 years from grazing trials conducted on rocky basaltic foothill range in a typical Mediterranean type environment were used to analyze effects of grazing system (seasonal

\footnotetext{
Authors are research scientists, Department of Natural Resources, Agricultural Research Organization, Bet Dagan (M.G. and N.G.S.); and professor, Department of Botany, Hebrew University of Jerusalem (I.N-M), Jerusalem, Israel. Contribution No. 2122-E, 1987 series from the ARO, The Volcani Center, Bet Dagan, Israel. Manuscript accepted 9 May 1989.
}

and yearlong), grazing method and stocking rate on estimates of herbage production. The objective of the study was to determine the sensitivity of herbage production at the experimental site to differences in grazing management over a period of years. Detailed analysis of animal performance in these experiments is reported elsewhere (Seligman and Gutman 1979, Gutman et al. 1989).

\section{Materials and Methods}

\section{Experimental Site}

The trial was conducted at the Karei Deshe Experimental Range in the lower Galilee of Israel, situated near the Jordan River and the Kinneret Lake (Sea of Galilee), lat. $32^{\circ} 55 \mathrm{~N}$, long. $35^{\circ} 35^{\prime} \mathrm{E}$, alt. $150 \mathrm{~m}$. The topography is hilly, with slopes generally less than $10 \%$. The soils are brown basaltic protogrumosols with variable depth but seldom deeper than $60 \mathrm{~cm}$ and with a rock cover of about $30 \%$ (Gutman 1977, Gutman and Seligman 1979). The vegetation is dominated by hemicryptophytes (forbs and grasses that have a perennial root system but lose most of the shoot during the dry summer) that include Hordeum bulbosum L., Echinops spp., and Psoralea bituminosa L. (Zohary 1972). There are also many annual species, some of which are palatable pasture plants (Avena sterilis L., Bromus spp., Trifolium spp., Medicago spp., and many others) while others are palatable for only short periods during the early vegetative stages (e.g., Scolymus maculatus L., Brassica nigra L., Echium plantagineum L.). Annual legumes comprise between 5 and $25 \%$ of the herbaceous cover; Hordeum bulbosum and annual grasses often account for more than $40 \%$ of cover (Seligman and Gutman 1979).

The rainy season begins in October or November and ends in April. Mean annual precipitation ( $\pm \mathrm{SD}$ ) during the experiment was $554 \pm 169 \mathrm{~mm}$, fluctuating between extremes of 322 and 761 $\mathrm{mm}$. Monthly precipitation is highly variable during the early and late months of the season, less so between December and March (Table 1). Seasonal growth of the range vegetation begins in November to December soon after the first rains. The herbage biomass exceeds $600 \mathrm{~kg} /$ ha DM usually by end of January. Growth continues in dependence on moisture and temperature conditions until it peaks during April. By mid-May the herbaceous

Table 1. Monthly precipitation at Karei Deahe during the experimental period (mm).

\begin{tabular}{|c|c|c|c|c|c|c|c|c|c|}
\hline Year & $75 / 76$ & $76 / 77$ & $77 / 78$ & $78 / 79$ & $79 / 80$ & $80 / 81$ & $81 / 82$ & Mean & $\begin{array}{l}\text { CV } \\
(\%)\end{array}$ \\
\hline $\begin{array}{l}\text { Month1 } \\
\text { Oct } \\
\text { Nov } \\
\text { Dec } \\
\text { Jan } \\
\text { Feb } \\
\text { Mar } \\
\text { Apr }\end{array}$ & $\begin{array}{r}0 \\
32 \\
145 \\
77 \\
96 \\
102 \\
51\end{array}$ & $\begin{array}{r}34 \\
180 \\
41 \\
104 \\
53 \\
114 \\
90\end{array}$ & $\begin{array}{r}0 \\
39 \\
202 \\
139 \\
67 \\
136 \\
16\end{array}$ & $\begin{array}{l}31 \\
35 \\
89 \\
66 \\
39 \\
52 \\
10\end{array}$ & $\begin{array}{r}46 \\
72 \\
215 \\
122 \\
128 \\
121 \\
57\end{array}$ & $\begin{array}{r}18 \\
3 \\
163 \\
263 \\
153 \\
107 \\
20\end{array}$ & $\begin{array}{r}0 \\
44 \\
17 \\
30 \\
187 \\
69 \\
11\end{array}$ & $\begin{array}{r}18 \\
58 \\
125 \\
114 \\
103 \\
100 \\
36\end{array}$ & $\begin{array}{r}105 \\
100 \\
62 \\
60 \\
53 \\
30 \\
83\end{array}$ \\
\hline Total & 503 & 616 & 599 & 322 & 761 & 727 & 358 & 554 & 31 \\
\hline
\end{tabular}

IDuring May to September inclusive, there was no significant rain during the study period. 
Table 2. Enercy concentration of pasture forage and supplementary feeds (Mcal/ke DM).

\begin{tabular}{lccc}
\hline \hline & $\begin{array}{c}\text { Metabolizable } \\
\text { energy } \\
\text { CME }\end{array}$ & \multicolumn{2}{c}{ Net energy } \\
\cline { 3 - 4 } Feed source & (gain) & $\begin{array}{c}\mathrm{CNE}_{\mathrm{m}} \\
\text { (maint) }\end{array}$ & $\begin{array}{c}\mathrm{CNE}_{\mathrm{x}} \\
\text { (gain) }\end{array}$ \\
\hline Green pasture forage & 2.3 & 1.43 & 0.84 \\
Dry pasture forage & 1.6 & 0.76 & 0.23 \\
Poultry litter (PL) & 1.56 & & \\
Wheat Straw (ST) & 1.45 & & \\
Barley grain (BG) & 3.04 & & \\
Energy expenditure grazing factor for grazing activity & \\
(GRZ) = 1.6 & & & \\
\hline
\end{tabular}

species are dry. During the green season the herbage is of high quality and animals gain rapidly. In the dry seasson, quality is sufficient for maintenance only during the first few months (Table 2).

\section{Experimental Design}

Six paddocks, in 2 blocks of 3 each, were available for the experiment. The paddocks were 25.5 to 33.0 ha in size and fenced so as to include equivalent proportions of the different range habitats in each paddock (Gutman and Seligman 1979). Throughout the experimental period, there were 3 grazing treatments. These were replicated twice, once in each block. The data for this study were taken from 2 consecutive experiments conducted at the same site. The first experiment (1976-1977) compared stocking rate and grazing method (continuous and rotational) during a season that began when the germinating pasture reached 500-700 $\mathrm{kg} /$ ha green herbage DM usually during January, and terminated at the end of the dry season in September. For about 4 months, between September and January, the animals were removed from the experimental paddocks. The herds for each paddock were reassembled each year, but the paddocks used for each grazing treatment were the same. The grazing treatments were seasonal continuous heavy (SCH), seasonal continuous light (SCL), and seasonal rotational heavy (SRH). The heavy treatments were stocked at 0.9 cows/ ha; the light treatment at 0.6 cows/ ha. In the rotational system, the paddocks were subdivided into 3 fenced subsections that were rotationally grazed with 3-5 week grazing periods, depending on the herbage growth (Gutman and Seligman 1985). The second experiment (1978 to 1982) used yearlong continuous grazing to compare 3 stocking rates: high ( 0.83 cows $/$ ha), moderate ( 0.67 cows/ha), and light ( 0.50 cows/ha), designated YCH, YCM, and YCL, respectively. The second experiment (1978-1982) began in January 1978 and was terminated at weaning on $19 \mathrm{July} 1982$. The herds in each stocking rate treatment stayed in their paddocks throughout the experiment except when taken to a central corral for weighing or veterinary treatment.

\section{Animals}

The cows were crosses and backcrosses between local (Balady) cows and Brahman, Hereford, and Simmental bulls. They were small and weighed on the average of $340 \mathrm{~kg}$. They were allocated between treatments so as to achieve evenly composed herds with equivalent initial weight and age structure. During the 'seasonal' grazing experiment, the herds were randomly assembled each year so that there was no carry-over effect of animal response from one year to the next. During the 'yearlong' grazing experiment, herds remained in the paddocks throughout the 5-year grazing trial. From July onwards, cows were supplemented ad libitum with poultry litter fed from large troughs to which all animals had free access. After the early rains, barley grain was mixed with poultry litter (20\% barley) and straw was given in daily rations that varied
Table 3. Daily energy requirements (Mcal/cow/d) and forage intake (ks/cow/d), derived from NRC (19\%).

W = liveweight, $\mathrm{kg} ; \mathrm{G}=$ daily EBW gain, $\mathrm{kg} / \mathrm{d} ; \mathrm{t}$ = days after conception

Cows

Variable

NE for maintenance

NE for gain

ME for maintenance

ME for gain

Forage DM intake/cow/day

Daily ME intake from PL and ST

Daily ME intake from BG

Pregnancy

$$
\begin{aligned}
& \text { Equation } \\
& \mathrm{NE}_{m}=0.077 \mathrm{~W}^{.75} \mathrm{GRZ} \\
& \mathrm{NE}_{\mathrm{E}}=6.25 \mathrm{G} \\
& \mathrm{ME}_{\mathrm{m}}=\mathrm{NE}_{\mathrm{m}} \mathrm{CME} / \mathrm{CNE}_{\mathrm{m}} \\
& \mathrm{ME}_{\mathrm{t}}=\mathrm{NE}_{\mathrm{m}} \mathrm{CME} / \mathrm{CNE}_{\mathrm{z}} \\
& \text { DMI }=\left(\mathrm{ME}_{\mathrm{m}}+\mathrm{ME}_{\mathrm{z}}-\mathrm{SUP}_{\mathrm{m}}-\right. \\
& \text { SUP. } / \text { CME } \\
& \text { SUP }_{\mathrm{m}}=\mathrm{PL} \text { intake }+\mathrm{ST} \text { intake } \\
& \text { SUP }_{\text {E }}=\text { BG intake } \\
& \mathrm{NE}_{\mathrm{p}}=\mathbf{a} \exp (\mathrm{b}) \\
& a=0.028(0.0149-0.0000407 t) \\
& b=0.05883 t-0.0000804 t^{2}
\end{aligned}
$$

Calves

Variable

NE for maintenance

NE for gain, medium frame, male

NE for gain, modium frame,

female

$$
\begin{aligned}
& \text { Equation } \\
& \mathrm{NE}_{\mathrm{w}}=0.077 \mathrm{~W}^{.75} \mathrm{GRZ} \\
& \mathrm{NE}_{\boldsymbol{\varepsilon}}=0.0493 \mathrm{~W}^{.75} \mathrm{G}^{1.097} \\
& \mathrm{NE} \quad=0.0686 \mathrm{~W}^{.75} \mathrm{G}^{1.119}
\end{aligned}
$$

with stocking rate. Supplementation ceased when green pasture became well established, usually between the middle and end of January (Tables 2 and 4). No supplements were given in the last year because the experiment terminated at weaning before the supplementary feeding period. In the seasonal experiment all cows were with calf at least at the beginning of the year.

In the yearlong experiment cows were all with calf only in the first year, after which the calving rate depended on the breeding

Table 4. Supplementary feed given to experimental herds (kg/ha).

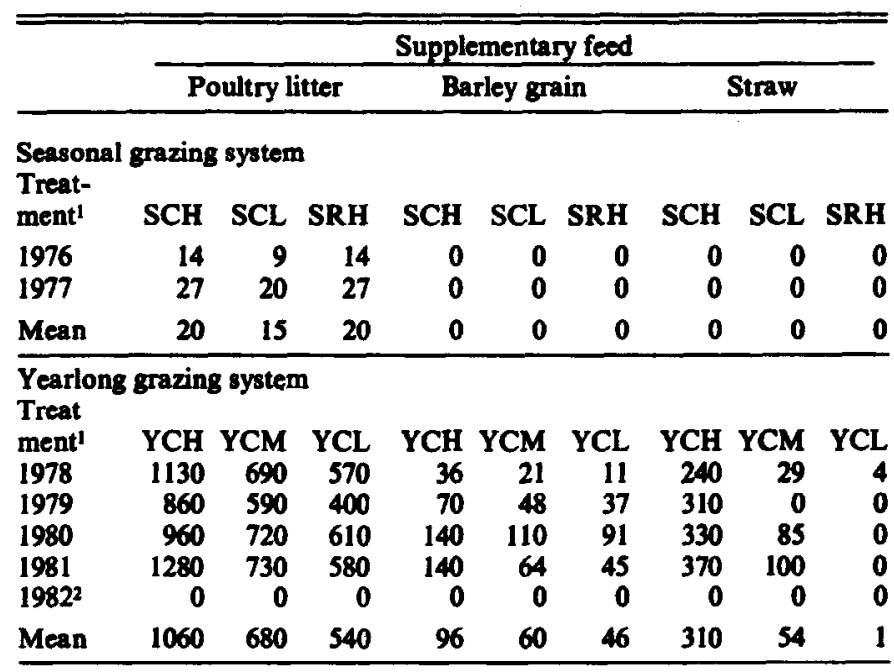

Analysis of variance (CH and $\mathrm{CL}$ treatments only)

\begin{tabular}{lcccc}
$\begin{array}{l}\text { Variable } \\
\text { Source }\end{array}$ & $\begin{array}{c}\text { Poultry litter } \\
\text { F-value }\end{array}$ & PR $>$ F & Barley grain \\
\hline Fystem & PR $>$ F \\
Stocking rate & 1284.7 & .0001 & - & - \\
$\mathbf{r}^{2}$ & 87.2 & .0001 & 21.6 & .0007 \\
CV (\%) & 0.99 & & 0.62 & \\
n & 7 & & 31 & \\
\hline
\end{tabular}

ISee Study Ares and Methods.

2Experiment terminated on 19 July 1982, before any supplements were given. 31978 to 1981 
performance of the cows in each experimental paddock. Bulls (grade Simmental) were with the cows between November and May. Calves generally were weaned between July and August. Pregnancy tests (by rectal palpation) were conducted after the last weaning and about 3 months after the bulls were removed from the herds. Cows in the yearlong experiment were replaced to maintain stocking rates only after skipping 2 consecutive breeding seasons or because of mortality.

Estimate of Forage Consumption and Herbage Production

The cows and calves were weighed during the experiment at 1- to 2-month intervals after withdrawal from water or feed for 18 hours. The normative consumption of pasture forage was calculated from net energy requirements of cows and calves for maintenance, physiological status, and live weight gain according to NRC standards (NRC 1984) using the equations shown in Table 3. Maintenance requirement was corrected to account for grazing activity by multiplication with a grazing factor (GRZ) of 1.6, as obtained in an experiment with sheep (Benjamin et al. 1977). The energy requirements used to calculate dry range forage consumption in the dry season were corrected for supplementary feed consumed during the period (Table 4). Forage intake was then calculated from net energy concentrations for maintenance and gain for green and dry range forage. These values were derived from estimates of metabolizable energy of local range vegetation (Table 2).

Amount of remaining dry herbage in each paddock was estimated at the end of the dry season in October before the first rains of the following rainy season. Estimates were based on calibrated ocular estimates (Tadmor et al. 1975) along permanent transects in the experimental paddocks; the herbage mass in $30025 \times 25-\mathrm{cm}$ quadrats in each paddock was estimated and 30 (every tenth quadrat) were clipped for calibration.

\section{Statistical Analyds}

The comparison between seasonal and yearlong grazing systems in this experiment cannot be conclusive because the systems were studied consecutively on the same range and not in parallel. Consequently, year effects overlap grazing system effects. Despite this problem, the grazing system is analysed as a separate factor because of the large differences between the systems: seasonal pasture utilization vs. yearlong, newly assembled herds each year vs. permanent herds, negligible supplementation vs. heavy supplementation. In addition, the 2 systems were compared on the same range in the same paddocks. Therefore, in the analysis of herbage consumption and production, year effects and system effects were analyzed separately. In order to facilitate the analysis, only systems that were comparable in both systems were included: SCL, SCH, YCL, and YCH. Data from the SRH and YCM treatments that were excluded from the statistical analysis are presented in Tables 3 to 5 for comparison.

Analysis of variance was calculated with the SAS (1985) general linear model (GLM) procedure. In the analysis, systems (seasonal and yearlong), stocking rates (high and low), year, and interactions were taken into account. Several versions of the model were tried but most interaction terms were not significant. In the final model only significant interactions and interactions of special interest were included. For each variable analyzed, the coefficient of determination $\left(r^{2}\right)$, the coefficient of variation of the residual sum of squares (CV), and the number of observations (n) are presented. In the analysis of animal responses, each individual animal in a year is an observation; hence, $\mathrm{n}$ is in the hundreds. In the analysis of herbage consumption and production, each paddock in a year is an observation; hence $\mathrm{n}=28$.
Table 5. Animal performance under seasonal and yearlong graxing syatems.

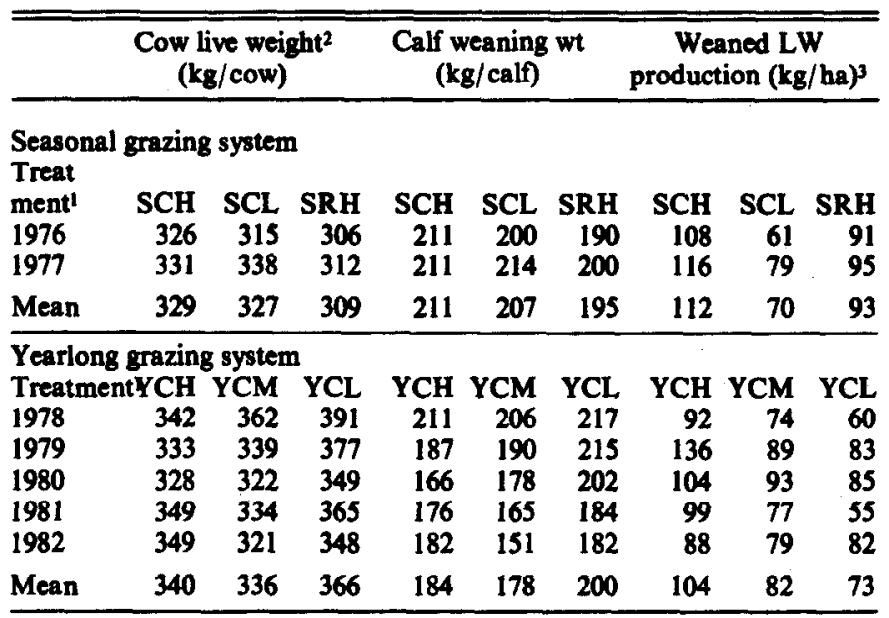

Analysis of variance (CH and $\mathrm{CL}$ treatments only)

\begin{tabular}{|c|c|c|c|c|c|c|}
\hline \multirow{2}{*}{$\begin{array}{l}\text { Variable } \\
\text { Source }\end{array}$} & \multicolumn{2}{|c|}{ Cow live weight } & \multicolumn{2}{|c|}{ Calf weaning wt. } & \multicolumn{2}{|c|}{ Weaned LW/ha } \\
\hline & F-value & $\operatorname{Pr}>\mathbf{F}$ & F-value & $\mathbf{P r}>F$ & F-value & $\mathbf{P r}>\mathbf{F}$ \\
\hline $\begin{array}{l}\text { System } \\
\text { Stocking }\end{array}$ & 17.5 & 0.001 & 18.2 & .0001 & 0.1 & .7533 \\
\hline $\begin{array}{c}\text { rate } \\
\text { SR * SYST }\end{array}$ & $\begin{array}{r}11.3 \\
6.1\end{array}$ & $\begin{array}{l}.0001 \\
.0136\end{array}$ & $\begin{array}{l}2.4 \\
6.7\end{array}$ & $\begin{array}{l}.1200 \\
.0102\end{array}$ & $\begin{array}{r}23.8 \\
0.6\end{array}$ & $\begin{array}{l}.0001 \\
.4625\end{array}$ \\
\hline$r^{2}$ & & & & & & 0.51 \\
\hline$\underset{n}{\text { CV (\%) }}$ & & & & & & $\begin{array}{l}21 \\
285\end{array}$ \\
\hline
\end{tabular}

ISee Study Area and Methods.

2 Cow liveweight at weaning.

In years 1976, 1977 and 1978 , weaned $L W$ production on range = weaning $w t$. - wt on entry into the experiment.

Individual animal observations.

sWhole paddock observations.

\section{Results}

In the seasonal grazing experiment, the cows consumed only small amounts of supplement (poultry litter in summer) while in the yearlong experiment, massive supplementation with poultry litter, barley, and straw were required, particularly in autumn and early winter. The amounts consumed increased with stocking rate (Table 4).

Mean cow weight per treatment at weaning varied between extremes of 310 and $390 \mathrm{~kg} /$ cow (Table 5). The cows in the seasonal experiment were slightly smaller than those in the yearlong experiment. The mean calf weights at weaning were similar at the beginning of each experiment, but on the average were lower in the yearlong experiment (Table 5). This can be ascribed to the fact that during the seasonal experiment the cows with calves were all pre-selected for early calving whereas in the yearlong experiment, later birth dates led to lower weaning weights. Overall, grazing treatment differences accounted for only 6 to $7 \%$ of the variation in cow and calf weight at weaning. Consequently, weaned calf weight per unit area was determined largely by stocking rate, which accounted for more than $50 \%$ of the variation. Differences between systems were not significant. During the driest year (1979), herbage production was average and animal production per unit area was the highest it had been during the whole experimental period (Table 6). An important factor that determined weaned liveweight production per unit area was the weaning rate. This, together with the fact that pasture inadequacy was partially made up with supplementary feed, contributed to the poor correlation between calf liveweight per unit area and herbage production or precipitation.

In each year the animals were in the paddocks for a shorter period during the seasonal experiment compared to the yearlong 
experiment. Consequently, the calculated mean annual pasture consumption per ha for equivalent stocking rates (CH and $C L$ ) was lower $(P<0.01)$, and unused herbage at the end of the grazing season was higher $(P<0.05)$ during the seasonal grazing experiment (Table 6). The mean total dry herbage production from the range, calculated by summing the forage consumption and residual

Table 6. Annual forage conaumption, realdual herbage at the end of the dry season and total dry matter production in the experimental treatments (kg/ha DM).

\begin{tabular}{|c|c|c|c|c|c|c|c|c|c|}
\hline & \multicolumn{3}{|c|}{ Forage consumption } & \multicolumn{3}{|c|}{ Residual litter } & \multicolumn{3}{|c|}{ Total production } \\
\hline $\begin{array}{l}\text { Season } \\
\text { Treat- } \\
\text { ment' } \\
1976 \\
1977\end{array}$ & $\begin{array}{c}\mathrm{SCH} \\
2200 \\
2270\end{array}$ & $\begin{array}{l}\text { SCL } \\
1420 \\
1720\end{array}$ & $\begin{array}{c}\text { SRH } \\
2020 \\
2190\end{array}$ & $\begin{array}{r}\text { SCH } \\
900 \\
660\end{array}$ & $\begin{array}{l}\text { SCL } \\
1610 \\
1230\end{array}$ & $\begin{array}{c}\text { SRH } \\
1130 \\
1000\end{array}$ & $\begin{array}{l}\text { SCH } \\
3100 \\
2930\end{array}$ & $\begin{array}{l}\text { SCL } \\
3030 \\
2950\end{array}$ & $\begin{array}{l}\text { SRH } \\
3150 \\
3190\end{array}$ \\
\hline Mean & 2240 & 1570 & 2100 & 780 & 1420 & 1070 & 3010 & 2990 & 3170 \\
\hline
\end{tabular}

Yearlong grazing system

Treat-

ment ${ }^{\prime}$ YCH YCM YCL

$\begin{array}{lllll}1978 & 2840 & 2670 & 2280\end{array}$

$1979 \quad 2610 \quad 2360 \quad 2160$

$1980 \quad 2710 \quad 2170 \quad 1960$

$\begin{array}{lllll}1981 & 2060 & 1820 & 1930\end{array}$

$\begin{array}{llll}19822 & 1960 & 1460 & 1320\end{array}$
YCH YCM YCL

$810 \quad 1080 \quad 1570$

$500 \quad 560 \quad 820$

$400 \quad 540 \quad 1010$

$550 \quad 770 \quad 1280$

$\begin{array}{llll}1020 & 1170 & 1500\end{array}$

$\begin{array}{lll}650 & 820 \quad 1230\end{array}$
YCH YCM YCL $3650 \quad 3750 \quad 3850$

$\begin{array}{lll}3110 & 2920 & 2980\end{array}$

$\begin{array}{lll}3110 & 2710 & 2970\end{array}$

$\begin{array}{lll}2610 & 2590 & 3210\end{array}$

$2980 \quad 2630 \quad 2820$

$3090 \quad 2920 \quad 3160$

Analysis of variance (CH and CL treatments only)

Variable Forage consumption Residual litter

Source F-value $\mathrm{Pr}>\mathrm{F}$ Total production

\begin{tabular}{lcccccc} 
Source & F-value & Pr $>$ F & F-value & Pr $>$ F & F-value & Pr $>$ F \\
\hline System & 16.2 & .0012 & 7.6 & .0154 & 1.5 & .2416 \\
Stocking & & & & & & \\
$\quad$ rate & 76.6 & .0001 & 134.7 & .0001 & 0.3 & .6018 \\
Year & 15.9 & .0001 & 14.8 & .0001 & 7.1 & .0017 \\
SR SYST & 1.8 & .1788 & 1.3 & .3050 & 1.3 & .3170 \\
r $^{2}$ & \multicolumn{2}{c}{0.93} & \multicolumn{2}{c}{0.94} & \multicolumn{2}{c}{0.76} \\
CV(\%) & \multicolumn{2}{c}{8} & \multicolumn{2}{c}{14} & \multicolumn{2}{c}{8} \\
n & & 28 & \multicolumn{2}{c}{28} & \multicolumn{2}{c}{28} \\
\hline
\end{tabular}

ISee Study Area and Methods

${ }^{2}$ Grazed up till 19 July 1982.

herbage, was strikingly similar in both experiments at about 3,000 $\mathrm{kg} / \mathrm{ha}$ (Table 6). Differences between treatments were very small and not significant. Differences between years were significant, mainly because of a particularly productive year in 1978 , the first year of the yearlong, continuous grazing experiment.

\section{Discussion}

Herbage production as estimated in the present study does not include plant material that was lost by decomposition or removed by other herbivores (insects, rodents, game). The calculation of herbage consumption by the beef herd, even though validated at the experimental site, is based on assumptions, such as the grazing factor, that add an element of uncertainty to the estimate. In addition, the measurement of residual herbage is subject not only to sampling error but is also affected by weathering and trampling of the dry material. An independent estimate of herbage production on the site during 1969-1973 was published by Gutman (1977). The vegetation was harvested from plots that were undisturbed by grazing or clipping until the end of the growing season. The mean dry matter yield $( \pm S D)$ for the 5 years was $3,100 \pm 503 \mathrm{~kg} / \mathrm{ha}$. The yields ranged between 2,490 and $3,650 \mathrm{~kg} / \mathrm{ha}$. These data do not account for leaf death and non-domestic herbivory, so they too are probably underestimates. However, they are direct measurements of above-ground ungrazed herbage production and at least confirm that the calculated data from the grazed plots are reasonable.
Studies in a drier Mediterranean site but where the soil is deep and there are no rocks, have shown that herbage production from native annual vegetation with $400 \mathrm{~mm}$ of annual precipitation, and with adequate plant nutrients, can produce $9,000 \mathrm{~kg} / \mathrm{ha}$ (van Keulen 1975, Benjamin et al. 1982). This would indicate that potential, climate-limited production in the study region is much higher than that observed in the present study. It must be concluded that soil resources, including restricted soil depth, are probably the dominant factor determining growth. This conclusion is supported by the fact that in the study area, fertilizer application, particularly nitrogen, has been shown to increase herbage production by almost 3 tons / ha dry matter, i.e., nearly double that measured in the present study (Gutman 1977). Basaltic protogrumosols are not deficient in phosphorus (Koyumdjisky and Dan 1969), but nitrogen availability can vary with mineralization, leaching, and $\mathrm{N}$-fixation by the highly variable annual legume component (Seligman and Gutman 1979).

The CV of the yields (uncorrected for treatment or year effects) from the clipped plots was $16.2 \%$ compared with $11.2 \%$ for that estimated from the grazed paddocks. Both these values are low when compared with other similar regions (Murphy 1970, Duncan and Woodmansee 1975, Le Houerou and Hoste 1977, Noy-Meir and Walker 1986). The CV of precipitation was $31 \%$ for total annual precipitation and between 30 and $105 \%$ for monthly precipitation (Table 1), values that are much larger than the variation in herbage production. In addition, correlation between total annual precipitation and total annual herbage production was low and not significant, even though the pattern of growth and the timing of the beginning and end of each season was determined mainly by precipitation distribution. The observed variation in total herbage production could also be explained by the seasonal distribution of precipitation and the duration of dry spells in the rainy season. These factors determine for how long a period in each season both soil moisture and soil nitrogen in a restricted rooting zone are optimal for plant growth. George et al. (1988) have shown that inter-annual variation in herbage production of California annual grasslands is related to accumulated degree days during the growing season. This relationship may explain the variation in the current experiment but could not be checked because of insufficient data. Degree days would not explain why the maximum herbage production at the study site is so much lower than potential herbage production under prevailing climatic conditions.

The lack of sensitivity of primary production to stocking rate and to grazing system needs clarification. If growth under the study conditions is determined mainly by a limited soil resource such as plant nutrients or moisture in a restricted rooting zone then it could be relativey independent of grazing regime because slower growth will cause a slower resource use and a longer growing season. This would be true unless growth rate and leaf area accumulation was reduced by grazing to so low a level that the growing season would be terminated before the vegetation utilized the available growth limiting plant nutrients (or moisture) in the soil (Noy-Meir 1978). For the latter to happen, stocking rates would have to be considerably higher than those that were imposed. At the heaviest stocking rate, 0.9 cows/ ha, and with mean green season herbage consumption rates of $11 \mathrm{~kg} / \mathrm{cow} / \mathrm{d}$ (Holzer, unpublished data), the maximum defoliation rate of about $10 \mathrm{~kg} / \mathrm{ha} / \mathrm{d}$ would be reached when green herbage availability ceased to limit intake at about $600 \mathrm{~kg} / \mathrm{ha}$ DM, usually about 6 to 8 weeks after germination (Gutman 1977). With a relative growth rate of $4 \%$, which is common during the early growth stages, the absolute growth rate at this stage is already $24 \mathrm{~kg} / \mathrm{ha}$, and increases as herbage accumulates. Hence, for most of the season, growth rate of the vegetation considerably exceeds defoliation rates even at the heaviest stocking and leaf biomass should always be well above the critical threshold for net growth 
(Noy-Meir 1975). Thus, even though the total amount of forage consumed by the herd varied with stocking rate, the total amount of herbage produced, did not.

\section{Conclusion}

We conclude that in the study area, where mean annual precipitation is more than $500 \mathrm{~mm}$ per annum, the interannual variability of herbage production of native Mediterranean-type grasslands growing on relatively shallow, rocky soil, was much lower than the variability of precipitation. Total annual herbage production was not particularly sensitive to total annual precipitation, grazing system, or to stocking rates between 0.5 and 0.9 small cows per ha. The highest herbage production achieved was much lower than potential production under prevailing climatic conditions, so production level must have been determined mainly by the seasonal patterns of nutrient and soil moisture availability in a restricted rooting zone.

\section{Literature Cited}

Benjamin, R.W., M. Chen, A.A. Degen, N. Abdul Axiz, and M.J. al Hadad. 1977. Estimation of the dry and organic intake of young sheep grazing a dry Mediterranean pasture and their maintenance requirements. J. Agr. Sci. (Camb.) 88:513-520.

Benjamin, R.W., E. Eyal, I. Noy-Meir, and N.G. Seligman. 1982. Intensive agropastoral systems in the Migda Experimental Farm, Northern Negev. Hassadeh 62:2202-5 (Hebrew with English summary).

Duncan, D.A., and R.G. Woodmansee. 1975. Forecasting forage yield from precipitation in California annual grassland. Range Manage. 28:327-9.

George, M.R., C.A. Raguse, W.J. Clawson, C.B. Wilson, R.L. Willoughby, N.K. MeDougall, D.A. Duncan, and A.F. Murphy. 1988. Correlation of degree days with annual herbage yields and livestock gains. J. Range Manage. 41:193-197.

Gutman, M. 1977. Primary production of transitional Mediterranean steppe. Ph.D. thesis. The Hebrew Univ. of Jerusalem, Israel.

Gutman, M., and N.G. Seligman. 1979. Grazing management of herbaceous Mediterranean foothill range in the upper Jordan valley and its effect on cattle and vegetation. J. Range Manage. 32:86-92.
Gutman, M., Z. Holzer, N.G. Seligman, and I. Noy-Meir. 1990. Stocking density and production of a supplemented beef herd grazing yearlong on Mediterranean grassland. J. Range Manage. (in press).

Gutman, M., and H.G. Seligman. 1985. Effect of grazing systems on productivity of herbaceous range in the Mediterranean climatic zone of Israel. Pamphlet 230, ARO, Bet Dagan, Israel.

Keulen, H. van. 1975. Simulation of water use and herbage growth in arid regions. Simulation Monographs. PUDOC, Wageningen.

Koyumdjisky, H., and J. Dan. 1969. Forms and availability of soil phosphorus as related to genetic characteristics of Israel soils. Pamphlet 131V. The Volcani Institute of Agricultural Research, Division of Scientific Publications, Bet Dagan.

Le Houerou, H.N., and C.H. Hoste. 1977. Rangeland production and annual precipitation relations in the Mediterranean basin and in the African Sahelo-Sudanian zone. J. Range Manage. 30:181-189.

Murphy, A.W. 1970. Predicted forage yield based on fall precipitation in Caifornia annual grasslands. J. Range Manage. 23:363-365.

Noy-Meir, I. 1975. Stability of grazing systems: an application of predatorprey graphs. J. Ecol. 63:459-481.

Noy-Meir, 1. 1978. Grazing and production in seasonal pastures: Analysis of a simple model. J. Appl. Ecol. 15:809-835.

Noy-Meir, I., and Walker, B.M. 1986. Stability and resilience in rangelands. p. 21-25. In: P.J. Joss, P.W. Lynch and O.B. Williams (eds.). Rangelands: A Resource Under Siege, Australian Acad. Sci., Canberra.

NRC. 1984. Nutrient requirements of domestic animals, No. 1. Nutrient requirements of beef cattle. 6th Revised Ed., Nat. Res. Counc. Washington, D.C.

Penning de Vries, F.W.T., and M.A. Djiteye. 1982. La productiVit des paturages saheliens. PUDOC, Wageningen, The Netherlands.

SAS. 1985. Users Guide: Statistics, Version 5. SAS Institute Inc. Cary, NC.

Seligman, N.G., and M. Gutman. 1979. Cattle and vegetation responses to management of Mediterranean rangeland in Israel. p. 616-618. In: D.N. Hyder (ed): Proc., Ist Inter. Rangeland Congress, Denver, Colo.

Tadmor, N.H., A. Brieghet, I. Noy-Meir, R.W. Benjamin, and E. Eyal. 1975. An evaluation of the calibrated weight-estimate method for measuring production in annual vegetation. J. Range Manage. 28:65-69.

Wallach, D., and M. Gutman. 1976. Environment dependent logistic equations applied to natural pasture growth curves. Agr. Meteorol. 16:389-404.

Zohary, M. 1973. Geobotanical foundations of the Middle East. Gustav Fischer Verlag, Stuttgart, and Swets and Zeitlinger, Amsterdam. 